WŁODZIMIERZ GOGŁOZA

Wydział Prawa i Administracji

Uniwersytetu Marii Curie-Skłodowskiej w Lublinie

ORCID: 0000-0002-0931-7413

\title{
GOĐAKIRKJA. ISLANDZKI KOŚCIÓŁ W OKRESIE WOLNEJ WSPÓLNOTY
}

Treść: Wstęp. - 1. Chrystianizacja Islandii. - 2. Wczesne islandzkie kościoły. - 3. Wczesne islandzkie duchowieństwo. -4 . Wprowadzenie dziesięciny. - 5. Spór o kontrolę nad majątkami kościelnymi i instytucjonalizacja islandzkiego Kościoła.

\section{Wstęp}

Średniowieczna Islandia z okresu funkcjonowania tzw. Wolnej Wspólnoty (Pjóðveldið), jest relatywnie dobrze udokumentowanym źródłowo przykładem społeczności przedpaństwowej, której ustrój polityczno-prawny oparty był o prywatne mechanizmy tworzenia, stosowania i egzekwowania prawa ${ }^{1}$. $Z$ tego też względu jest ona przedmiotem wielu badań podejmowanych przez przedstawicieli licznych dyscyplin naukowych, w tym historii, archeologii, antropologii politycznej, jak również ekonomii instytucjonalnej i ekonomicznej analizy prawa ${ }^{2}$. Powinna ona również wydać się interesującą badaczom dziejów Kościoła, z uwagi na zakres kontroli jaką przedstawiciele islandzkiego laikatu sprawowali nad majątkiem kościelnym, unikalny

\footnotetext{
${ }^{1}$ D.D. Friedman, Private Creation and Enforcement of Law: A Historical Case, Journal of Legal Studies 8 (1979), s. 399-415.

${ }^{2}$ Zob. np. A Companion to Old Norse-Icelandic Literature, red. R. McTurk, Oxford 2005.
} 
status duchownych oraz odbiegający od standardów prawa kanonicznego kształt lokalnej dziesięciny. Celem niniejszego artykułu jest dokonanie rekonstrukcji funkcjonowania średniowiecznego islandzkiego Kościoła we wszystkich wyżej wymienionych obszarach, w oparciu o staroislandzkie prywatne zbiory prawa Grágás ${ }^{3}$, XII i XIII-wieczne źródła narracyjne oraz akty donacyjne najstarszych prywatnych kościołów ${ }^{4}$.

\section{Chrystianizacja Islandii}

W staronordyckich źródłach narracyjnych chrystianizacja Skandynawii przedstawiana jest jako efekt zorganizowanego wysiłku zachodnich misjonarzy działających bądź to z inspiracji, bądź też przy poparciu lokalnych władców ${ }^{5}$. Nie negując wpływu elit politycznych na przebieg konwersji współcześni badacze podkreślają jednak, iż

\footnotetext{
${ }^{3}$ Grágás, Islondernes lovbog i fristatens tid, udgivet efter det kongelige Bibliotheks Haandskrift og oversat af Vilhjálmur Finsen, for det nordiske Literatur-Samfund, Kjøbenhavn 1852. Na temat wartości poznawczej tego źródła zob. zwł. G. KARLSson, Goðamenning. Staða og áhrif goðorðsmanna í pjóðveldi Íslendinga, Reykjavík 2004, s. 28-59; P. Foотe, Reflections on Landabrigðispáttr and Rekapáttr in Grágás, w: Tradition og historieskrivning. Kilderne til Nordens ældste historie, red. K. Hastrup, P.M. Sørensen, Arhus 1987, s. 58-59; M. SteIn-Wilkeshuis, Laws in Medieval Iceland, Journal of Medieval History 12 (1986), s. 37-53. Wszystkie dalsze odwołania do Grágás w głównej części niniejszego artykułu dotyczą wydania opublikowanego w Laws of Early Iceland Grágás The Codex Regius of Grágás with Material from Other Manuscripts, vol. I \& II, red. A. Dennis, P. Foote, R. Perkins, Winnipeg 1980. Dla ułatwienia odnajdywania odpowiednich fragmentów w tekście używam następującego zapisu: rzymska liczba wskazuje na tom, liczba arabska na paragraf, zaś arabska liczba zapisana subskryptem na stronę, na której on się znajduje. Dla przykładu GII $255_{222}$ wskazuje na paragraf 255 opublikowany w drugim tomie Grágás na stronie 222. Symbol $\$$ poprzedzający numer paragrafu znamionuje dodatek spoza głównego manuskryptu.

${ }^{4}$ Odnośnie do źródeł narracyjnych zob. J. Kristjúnsson, Eddas and Sagas. Iceland's Medieval Literature, Reykjavik 2007 oraz prace zebrane w tomie Sagi islandzkie. Zarys dziejów literatury staronordyckiej, red. J. Morawiec, Ł. Neubauer, Warszawa 2015.

${ }^{5}$ A. Winroth, The Conversion of Scandinavia: Vikings, Merchants, and Missionaries in the Remaking of Northern Europe, New Haven 2012, s. 102-120.
} 
oficjalne porzucenie pogaństwa zostało poprzedzone w nordyckim obszarze kulturowym wielowiekowym procesem spontanicznego przenikania chrześcijańskich idei do świadomości Skandynawów za sprawą ich kontaktów z mieszkańcami schrystianizowanej Europy ${ }^{6}$. Kontakty te mogą sięgać nawet czasów rzymskich, jednak szczególnej intensyfikacji uległy w okresie burzy normańskiej. Zarówno źródła pisane, jak i archeologiczne odnoszące się do ekspansji Normanów nie pozostawiają wątpliwości co do tego, iż wielu z nich było zaznajomionych z religią chrześcijańską na długo przed oficjalną konwersją krajów skandynawskich datowaną zazwyczaj na przełom X i XI wieku?

Według tradycji utrwalonej w Landnámabók (dosłownie „Księga zasiedlenia” - średniowieczna islandzka kronika mająca stanowić zapis przebiegu kolonizacji wyspy ${ }^{8}$ ) wśród prominentnych islandzkich osadników znajdowali się chrześcijanie ${ }^{9}$. Zgodnie z jej treścią wkrótce po dotarciu na wyspę Örlygur Hrappson wzniósł w Patreksfjörður (nazwanego tak na cześć św. Patryka apostoła Irlandii) kościół pod patronatem świętego Kólmukilli (św. Kolumbana, zm. w 597 roku fundatora kilkudziesięciu klasztorów i kościołów na terenie Szkocji i północnej Anglii, Landnámabók, rozdz. 15). Zdaniem redaktorów Księgi Zasiedlenia chrześcijanami mieli być również Ketill zwany przez pogan Głupcem (fiflski), Auður Mądra (djúpúðga), Ásólfr

${ }^{6}$ S. BRINK, Christianisation and the Emergence of the Early Church in Scandinavia, w: The Viking World, red. S. Brink, N. Price, London 2008, s. 622-626.

${ }^{7}$ A. Winroth, The Age of the Vikings, Princeton 2014, s. 198-201.

${ }^{8}$ Íslendingabók; Landnámabók, Íslenzk fornitr 1, red. J. Benediktsson, Reykjavík 1968. Zob. też Landnámabók. The Book of Settlements, red. H. Pálsson, P. Edwards, Manitoba 1972. Szerzej na temat tego źródła w J. BenedikTsson, Landnámabók. Some Remarks on its Value as a Historical Source, Saga-Book of the Viking Society 17 (1966-69), s. 275-292; A. FriĐriksson, O. Vésteinsson, Creating a Past: A Historiography of the Settlement of Iceland, w: Contact, Continuity, and Collapse: The Norse Colonization of the North Atlantic, red. J.H. Barrett, Turnhout 2003, s. 139-161.

${ }^{9}$ J. Jesch, Some Early Christians in Landnámabók, w: The Sixth International Saga Conference Workshop Papers: Christianity and West Norse Literature. Transmission and Editing of Texts, red. J. Louis-Jensen, C. Sanders, P. Springborg, Copenhagen 1985, s. 513-529. 
z Ósar, Jörundr enn kristni i Helgi bjóla (Landnámabók odpowiednio rozdz. 320, 97, 24, 346, 14). Wszyscy oni mieli trafić na Islandię za pośrednictwem Wysp Brytyjskich, głównie Hebrydów, co może wskazywać na celtycki rodowód ich chrześcijaństwa ${ }^{10}$. Można również zasadnie podejrzewać, iż chrześcijanami była większość irlandzkich niewolników sprowadzonych w dużych ilościach na Islandię w okresie zasiedlenia ${ }^{11}$. Redaktorzy zachowanych wersji Landnámabók wyraźnie zastrzegają jednak, iż choć część z prominentnych osadników pozostawała wierna chrześcijaństwu do końca swego życia, ich dzieci porzuciły wiarę rodziców „wzniosły świątynie i składały ofiary, przez co Islandia pozostawała kompletnie pogańską przez około 120 lat" (Landnámabók, rozdz. 399) ${ }^{12}$. Zastrzeżenie to znajduje odzwierciedlenie w wynikach współczesnych badań archeologicznych dowodzących, iż przez cały X wiek Islandczycy chowali zmarłych z zachowaniem tradycyjnych pogańskich zwyczajów ${ }^{13}$.

W świetle dostępnych nam źródeł narracyjnych sytuacja ta miała się zmienić dopiero za sprawą wysiłku szeregu misjonarzy, którzy pod koniec X wieku zaczęli nawracać mieszkańców Islandii na chrześcijaństwo $^{14}$. Część z nich, jak np. niemiecki biskup Friðrekr, miała pojawić się na wyspie na zaproszenie Islandczyków, którzy przyjęli

\footnotetext{
${ }^{10} \mathrm{~J}$. UlfF-MøLLER, The Origin of the Book of Settlement and Celtic Christianity in Iceland, Studi e Materiali di Storia Delle Religioni 82 (2016), s. 887-915.

${ }^{11}$ R.M. KARRAS, Slavery and Society in Medieval Scandinavia, New Haven 1988, s. $80-81$.

${ }^{12} \mathrm{Na}$ temat pogaństwa na Islandii zob. L.P. SŁUPECKI, Forn sidr. Pogaństwo jako sposób życia dawnych Islandczyków, w: Bogowie i ich ludy. Religie pogańskie a procesy tworzenia się tożsamości kulturowej, etnicznej, plemiennej i narodowej w średniowieczu, red. L.P. Słupecki, Wrocław: 2008, s. 39- 47.

${ }^{13}$ A. FriĐriksson, Viking Burial Practices in Iceland, w: Kuml og haugfé í heiðnum sið á Íslandi, red. A. Friðriksson, Reykjavík 2000, s. 549-610.

${ }^{14}$ D. Sтrӧмвӓск, The Conversion of Iceland. A Survey, London 1975; K. GJerSET, History of Iceland, New York 1925, s. 48-70; J. JóH ANNESson, Íslendinga saga. A History of the Old Icelandic Commonwealth, Manitoba 1974, s. 124-138; R. Rut Kowski, Dzięki komu Islandczycy nawrócili się na chrześcijaństwo? Konwersja widziana oczami średniowiecznych autorów, Kwartalnik Historyczny 121 (2014), s. 5-40; S. SAGAN, Kościót państwowy Islandii, Studia z Prawa Wyznaniowego 10 (2007), s. 63-65.
} 
wiarę w Chrystusa w czasie swych zagranicznych podróży, inni mieli tam trafić z inicjatywy Arcybiskupa Hamburga-Bremy Adaldaga (sprawującego tą funkcję w latach 937-988), czy zwłaszcza norweskiego władcy Óláfa Tryggvasona (995-1000). Ten ostatni miał wysłać do Islandii około 997 roku księdza o imieniu Pangbrandr, a gdy jego misja chrystianizacyjna zakończyła się niepowodzeniem (został zmuszony do opuszczenia wyspy po tym jak zabił kilka szydzących z niego pogan), król miał uwięzić przebywających w Norwegii prominentnych Islandczyków grożąc, iż jeśli ich rodacy nie przyjmą wiary w Chrystusa, zakładnicy zostaną zgładzeni (Óláfs saga Tryggvasonar, rozdz. 41). Według relacji zawartej w Íslendingabók (dosłownie „Księga Islandczyków”, XII-wieczna kronika uznawana współcześnie za jedno $\mathrm{z}$ bardziej wiarygodnych staroislandzkich źródeł ${ }^{15}$ ), latem roku 1000 (według części współczesnych autorów w 999 r. $^{16}$ ) podczas dorocznego spotkania islandzkiego Zgromadzenia Powszechnego (Alpingi) ultimatum Óláfa mieli przekazać Islandczykom Gizurr Biały i Hjalti Skeggjason - dwaj islandzcy wodzowie ( goðar), którzy kilka lat wcześniej przyjęli chrzest z rąk Pangbrandra (Íslendingabók, rozdz. 7).

Jak relacjonuje autor Księgi Islandczyków Ari fróði Porgilsson, gdy Gizurr i Hjalti dotarli wraz z dużą grupą swych sprzymierzeńców na pole wiecowe (Pingvellir) i ogłosili ze Skały Prawa (Lögberg) cel swej misji, uczestnicy Zgromadzenia Powszechnego podzielili się na dwa wrogie obozy „i w rezultacie, jeden za drugim, tak chrześcijanie jak i poganie, zaczęli wzywać świadków na dowód tego, iż uznają

${ }^{15}$ Íslendingabók; Landnámabók, Íslenzk fornitr 1, red. J. Benediktsson, Reykjavík 1968. Zob. też Íslendingabók and Kristnisaga - The Book of Icelanders, and The Story of the Conversion, Viking Society for Northern Research Text Series, vol. XVIII, red. S. Grønlie, London 2006. Na temat tej kroniki, jej autora i kwestii historycznej wiarygodności utrwalonego w niej przekazu zob. R. Rutкowski, „A ja nazywam się Ari”. O najstarszej kronice islandzkiej i jej autorze, w: Autor i jego dzieło w wiekach średnich, red. A. Laskowska, M. Sas, Warszawa 2014, s. 63-76 oraz S. JA KoBsson, Narrating History in Iceland: The Works of Ari Porgilsson, Arkiv för Nordisk Filologi (132) 2017, s. 75-99.

${ }^{16}$ Ó. EINARSDótTIR, Studier i kronologisk metode i tidlig islandsk historieskrivning, Stockholm 1964, s. 72-82. 
stronę przeciwną za wyjętą spod prawa, po czym opuścili Lögberg" (Íslendingabók, rozdz. 7).

W opinii części współczesnych badaczy konflikt ten miał charakter tyleż religijny, co konstytucyjny ${ }^{17}$. Jeśli bowiem prawdą jest, jak utrzymują autorzy staroislandzkich źródeł narracyjnych, iż pełnienie przez islandzkich wodzów funkcji publicznych było nierozerwalnie związane z pogańskimi praktykami religijnym, jak np. składaniem ofiar nordyckim bogom i przysięgami na pierścienie ceremonialne (w j. staroislandzkim stallahringr, hringr lub baugr, zob. np. Eyrbyggja saga, rozdz. 4; Víga-Glúms saga, rozdz. 25; Kjalnesinga saga, rozdz. 2) ${ }^{18}$, to goðar, którzy zdecydowali się na przyjęcie chrześcijaństwa oraz stowarzyszeni z nimi gospodarze, znaleźli się automatycznie poza systemem instytucjonalnym kraju. Stąd też część badaczy odczytuje relacje przechowywane w źródłach narracyjnych, dotyczących obustronnego wyjęcia spod prawa jako sugestię, iż wodzowie ochrzczeni przez Pangbrandra zdecydowali się na powołanie własnego wiecu i własnego systemu prawnego ${ }^{19}$. W starszych pozycjach literatury przedmiotu można nawet znaleźć sugestie jakoby miejscem obranym przez chrześcijańskich goðar na nowe zgromadzenie publiczne był Biskupstungur, gdzie archeolodzy odkryli pozostałości zabudowań interpretowanych jako búðir (szałasów wznoszonych w pobliżu miejsc, w których zbierały się wiece publiczne) ${ }^{20}$. Powyższe hipotezy, tj. zarówno ta odnosząca się do powołania nowego wiecu przez

\footnotetext{
${ }^{17}$ L.P. SŁu Pecki, Konwersja jako zamach stanu. Przyjęcie chrztu przez Islandię w 1000 roku, w: Zamach stanu w dawnych społecznościach, red. A. Sołtysiak, J. Olko, Warszawa 2004, s. 237-248.

${ }^{18}$ O. Sundqvist, An Arena for Higher Powers. Ceremonial Buildings and Religious Strategies for Rulership in Late Iron Age Scandinavia, Leiden 2016 s. 167-186; L.P. SŁupecki, Pagan Temple - Christian Church. The Problem of Old Norse Temples, w: Between Paganism and Christianity in the North, red. L.P. Słupecki, J. Morawiec, Rzeszów 2009, s. 37-38.

${ }^{19}$ N.P. NJARĐvík, Birth of a Nation. The Story of Icelandic Commonwealth, Reykjavik 1978, s. 57; M. MAgnússon, Iceland Saga, Gloucestershire 2005, s. 165.

${ }^{20} \mathrm{~J}$. JóH annesson, Íslendinga..., s. 131.
} 
chrześcijan, jak i ta dotycząca ewentualnego miejsca jego spotkania, choć intrygujące są jednakże niemożliwe do zweryfikowania.

Relacje zawarte w Íslendingabók (rozdz. 7), Óláfs saga Tryggvasonar (rozdz. 41) oraz w opartej na Księdze Islandczyków a zarazem znacznie od niej obszerniejszej Kristni saga (rozdz. 12) świadczą, iż - przynajmniej w przekonaniu sögumenn - konflikt do jakiego doszło w trakcie rzeczonego spotkania Alpingi został zażegnany pokojowo. Stojąc w obliczu najpoważniejszego kryzysu w dotychczasowej historii swego kraju Islandczycy mieli rozstrzygnąć go na drodze arbitrażu. Kompromisowy werdykt, który uchronił wyspiarzy przed walkami, jakie towarzyszyły chrystianizacji Norwegii, miał według Ariego wydać Porgeir Porkelsson - Głosiciel Prawa, pełniący tą funkcję w latach 985-1001. W staroislandzkiej tradycji Porgeir jest uznawany za poganina, miał on jednak miećlicznych przyjaciół i krewnych wśród stronnictwa chrześcijan i to właśnie jeden z nich - Hallr Porsteinsson (jeden z kilku goðar, którzy przyjęli chrzest z rąk Pangbrandra) - miał go przekonać do podjęcia się roli arbitra ${ }^{21}$.

„[Następnego dnia] Porgeir wezwał, by mężowie szli pod Skałę Prawa. I wtedy rozpoczął swoją mowę, gdy lud się tam zebrał, i mówił, iż wydaje mu się, że stan umysłów ludzkich znajdzie się w złej fazie, jeśli cały lud nie będzie miał jednego prawa, i przekonywał mężów w różny sposób, że nie mogą do tego dopuścić; mówił, że doprowadziłoby to do niezgody i z całą pewnością można przewidzieć, że takie walki powstałyby wśród ludu, od których kraj by spustoszał. Opowiadał o tym, jak przez długi czas królowie norweski i duński toczyli wojnę między sobą i bitwy, póki ludność nie doprowadziła do zgody między nimi, choć oni sami tego nie chcieli. I owo paktowanie wypadło tak, iż niebawem posłali sobie wzajemnie drogocenne dary,

${ }^{21}$ Warto w tym miejscu zaznaczyć, iż Ari używa w tym fragmencie swej kroniki wieloznacznego wyrażenia kaupa at, które może oznaczać zarówno „przekonać”, jak i „zapłacić”, stąd też zarówno w późniejszych staroislandzkich źródłach (zob. np. Njáls saga rozdz. 105, Kristni saga rozdz. 12), jak i we współczesnej literaturze przedmiotu można znaleźć liczne spekulacje co do tego, czy Porgeir nie został przekupiony. J. JóH ANnEsson, Íslendinga..., s. 134-135. 
a pokój ten trwał tak długo, jak obaj żyli. «Uważam teraz za wskazane - powiedział - byśmy również nie pozwolili rządzić tym, którzy najostrzej chcą występować przeciwko sobie i pośredniczmy w ten sposób w sprawie między nimi, że obydwie strony uzyskają coś ze swych żądań, ale zachowajmy wszyscy jedno prawo i jeden zwyczaj. Okaże się prawdą, że jeżeli zerwiemy prawo, to zerwiemy i pokój». I taki był skutek tej mowy, że obydwie strony zgodziły się na to, by wszyscy mieli jedno prawo, to, które on uzna za stosowne wygłosić. Wówczas zostało ustanowione prawem, że wszyscy mają zostać chrześcijanami i przyjąć chrzest, ci, którzy jeszcze są nieochrzczeni tutaj w kraju; ale co do wynoszenia niemowląt miało obowiązywać dawne prawo, tak samo jak co do spożywania koniny. Mogli ludzie składać ofiary bogom, jeśli by chcieli, w tajemnicy, ale miała być za to trzyletnia banicja, jeżeli by na to stawiono świadków. Po upływie kilku zim jednak zanikło pogaństwo całkowicie"22.

Relacje dotyczące pokojowego przyjęcia przez Islandię chrześcijaństwa istotnie odbiegają od tych dotyczących konwersji krajów skandynawskich, gdzie nowa wiara spotkała się zazwyczaj ze zorganizowanym oporem znacznej części lokalnych społeczności ${ }^{23}$. W literaturze przedmiotu można wręcz spotkać sugestie, jakoby tradycja utrwalona w Íslendingabók była „zbyt piękna, by mogła być prawdziwa”"24. Część badaczy podkreśla również, iż zachowane źródła prezentują „wyłącznie chrześcijańską wersję wydarzeń” ${ }^{25}$ i że

${ }^{22}$ Íslendingabók, rozdz. 7, tłum. R. Rutkowski, Dzięki komu..., s. 11.

${ }^{23}$ W. Duczko, The Missionary Period of Christianization in Vikig-Age Denmark and Sweden, w: Christianization of the Baltic Region, red. J. Gąssowski, Pułtusk 2004, s. 117-146. Warto w tym miejscu nadmienić, iż gdy w roku 1000 zmarł Óláfr Tryggvason w Norwegii doszło do pogańskiej reakcji, zjawisko to nie dotknęło natomiast Islandii. J.L. BYock, Medieval Iceland: Society, Sagas, and Power, Berkeley 1988, s. 143.

${ }^{24}$ M. Magnússon, Iceland..., s. 168-169. Zob. też P. UrbańCZy K, Violent Peace in Medieval Iceland, w: Consensus or Violence? Cohesive Forces in Early and High Medieval Societies (9th-14th c.), red. S. Moździoch, P. Wiszewski, Wrocław 2013, s. 216-217.

${ }^{25}$ N.P. NJARĐvík, The Birth..., s. 59. 
„z całą pewnością nie przekazują one całej prawdy” na temat przebiegu konwersji ${ }^{26}$. Niemniej jednak w swym ogólnym zarysie przekazy dotyczące przebiegu chrystianizacji Islandii są uznawane przez współczesnych badaczy za wiarygodne ${ }^{27}$. Informatorem Ariego fróði, który jest naszym głównym źródłem wiedzy na temat konwersji Islandczyków, miał być ksiądz Teitr Ísleifsson (zm. w 1111 roku), wnuk Gizzura Białego, syn pierwszego biskupa Islandii Ísleifa Gizurarsona (1006-1080) i brat następcy tego ostatniego Gizzura Ísleifssona (1042-1118). Można więc zasadnie podejrzewać, iż w jego rodzinie informacje na temat przebiegu konwersji były przechowywane ze szczególną pieczołowitością, nie możemy jednak mieć pewności co do ich obiektywizmu. Ponadto w literaturze wskazuje się na fakt, iż ciąg zdarzeń przedstawiony w Íslendingabók mieści się w logice systemu polityczno-prawnego Islandii ${ }^{28}$. Szczególnie znamiennym w tym względzie są jednak wyniki badań archeologicznych dotyczących zwyczajów pochówkowych Islandczyków, z których wynika, iż z początkiem XI wieku całkowicie zaprzestano na Islandii grzebania zmarłych na sposób pogański. W islandzkich źródłach archeologicznych brak jest okresu przejściowego charakterystycznego dla konwersji większości krajów skandynawskich, w których jeszcze przez kilkadziesiąt lat od oficjalnego chrztu stawiano kamienie/stele runiczne, a arystokratycznych zmarłych grzebano pod pogańskimi kurhanami ${ }^{29}$.

\footnotetext{
${ }^{26}$ S. BRINK, Christianisation and the Emergence of the Early Church in Scandinavia, w: The Viking..., s. 625.

${ }^{27}$ J. Jochens, Late and Peaceful: Iceland's Conversion through Arbitration in 1000, Speculum 74 (1999), s. 621-655.

${ }^{28}$ J.L. Byоск, Viking Age Iceland, London 2001, s. 301.

${ }^{29}$ A. FriĐriksson, O. Vésteinsson, Landscapes of Burial: Contrasting the Pagan and Christian Paradigms of Burial in Viking Age and Medieval Iceland, Archaeologia Islandica 9 (2011), s. 50-64. Należy wszelako zaznaczyć, iż w wielu przypadkach odróżnienie grobu późnopogańskiego od wczesnochrześcijańskiego przysparza archeologom istotnych trudności.
} 


\section{Wczesne islandzkie kościoły}

Chrystianizacja krajów pogańskiej Europy jest ściśle związana z procesami państwotwórczymi ${ }^{30}$. Nowa wiara o jednoznacznie monocentrycznym charakterze stanowiła ideę, wokół której lokalni arystokraci aspirujący do przejęcia/umocnienia władzy nad krajem mogli unifikować swych zwolenników. Paralele jakie autorzy średniowiecznych źródeł narracyjnych snują między wiarą w jednego Boga, a sprawowaniem władzy przez jednego króla nie pozostawiają wątpliwości, iż wodzowie krzewiący nową religię mieli na celu nie tylko zbawienie własnej duszy, ale i centralizację swych rządów ${ }^{31}$.

Analiza treści staronordyckich źródeł jednoznacznie wskazuje, iż także konwersja Skandynawów miała wymiar polityczny ${ }^{32}$. $\mathrm{Na}$ Islandii, w przeciwieństwie do regionów, z których pochodzili osadnicy, nie towarzyszyła jej jednak koncentracja władzy, co sugeruje iż w początku XI wieku organizacja polityczna Wspólnoty nie osiągnęła jeszcze punktu, w którym osoby zajmujące uprzywilejowaną pozycję w kraju, były w stanie efektywnie narzucać swą wolę niezwiązanym z nimi osobom trzecim ${ }^{33}$. Policentryczna struktura polityczna Islan$\mathrm{dii}^{34}$ miała również istotny wpływ na przebieg rozwoju lokalnych instytucji kościelnych, który pod wieloma względami znacznie odbiega tak od kontynentalnych, jak i skandynawskich wzorców.

Praktycznie w żadnym innym europejskim kraju osoby świeckie nie sprawowały tak dużej kontroli nad instytucjami kościelnymi jak

${ }^{30}$ Zob. zwł. prace zebrane w tomie Christianization and the Rise of Christian Monarchy: Scandinavia, Central Europe and Rus'c. 900-1200, red. N. Berend, Cambridge 2007.

${ }^{31}$ S. BAgGe, Christianization and State Formation in Early Medieval Norway, Scandinavian Journal of History 30 (2005), s. 115-116.

${ }^{32}$ Tenże, Cross and Scepter. The Rise of the Scandinavian Kingdoms from the Vikings to the Reformation, Princeton 2014, s. 60-118.

${ }^{33}$ O. VÉsteinsson, The Christianization of Iceland. Priest, Power and Social Change 1000-1300, Oxford 2000, s. 18-19.

${ }^{34}$ W. GogŁozA, Upadek policentrycznego porządku konstytucyjnego średniowiecznej Islandii w świetle teorii stanu natury Roberta Nozicka, w: S. Górka, T. Słupik, G. Szewczyk (red.), Oblicza wolności. Od klasycznego liberalizmu do libertarianizmu, Katowice 2013, s. 47-72. 
w średniowiecznej Islandiii ${ }^{35}$. Aż do końca XIII wieku niemal cały majątek islandzkiego kościoła był zarządzany przez członków laikatu (patrz niżej). Normy prawa kościelnego uznawano na Islandii za część prawa krajowego (landslög) i podlegały tym samym zasadom uchwalania i promulgacji co normy świeckie. Gdy między 1122 a 1133 rokiem islandzcy biskupi podjęli się spisania lokalnych norm prawa kanonicznego (obecnie zwanych Starymi Prawa Chrześcijańskimi - Kristinn réttr hinn forni - w odróżnieniu od Nowych Praw Chrześcijańskich Kristinn réttr hinn nýi przyjętych w 1275 roku), opracowany przez nich projekt został odczytany podczas posiedzenia Zgromadzenia Prawodawczego (Lögrétta) i poddany głosowaniu przez jej członków, którymi byli świeccy wodzowie $\left(G I 1_{50}\right)$. Mimo protestów norweskich arcybiskupów obowiązki nakładane przez nich na Islandczyków były traktowane przez tych ostatnich jako nýmoeli ( $\mathrm{tj}$. nowe prawa uchwalone przez Zgromadzenie Prawodawcze, zob. np. GI $18_{50-51}$ ), które zgodnie z lokalnie obowiązującym prawem dla utrzymania mocy obowiązującej musiały być ogłaszane ze Skały Prawa podczas trzech kolejnych spotkań Alpingi (GI 1951 w związku z GI $\left.111_{192}\right)^{36}$. Kiedy w połowie XIII wieku dokonano prywatnego spisu praw obowiązujących na Islandii (Grágás) włączono do nich ogół obowiązujących wówczas na Islandii norm kanonicznych, tworząc Sekcję Praw Chrześcijańskich (Kristinna laga páttr, GI 1-19 ${ }_{23-51}$ ). W rękach osób świeckich pozostawał też wybór biskupów elektów, a oni sami aż do połowy XII wieku rekrutowali się spośród lokalnych wodzów (właścicieli goðorð). Wpływ islandzkiej arystokracji na bieżące funkcjonowanie lokalnego kościoła był tak duży, iż we współczesnej literaturze przedmiotu islandzki kościół okresu Pjóðveldið zwykło się określać mianem goðakirkja, to jest „kościołem wodzów”37.

\footnotetext{
${ }^{35}$ J.L. Byock, Governmental Order in Early Medieval Iceland, Viator: Medieval and Renaissance Studies 17 (1986), s. 34.

${ }^{36}$ S. BAgge, From Viking Stronghold to Christian Kingdom. State Formation in Norway, c. 900-1350, Copenhagen 2010, s. 202.

${ }^{37}$ S. NordAL, Icelandic Culture, Ithaca, s. 245.
} 
Za główną przyczynę tak daleko idącego wpływu laikatu na funkcjonowanie islandzkiego kościoła uznaje się w literaturze kontrolę, jaką osoby prywatne sprawowały nad majątkiem kościelnym ${ }^{38}$. O ile na terenie Skandynawii kościoły parafialne zazwyczaj wznoszone były wspólnym wysiłkiem lokalnych społeczności, o tyle na Islandii wszystkie świątynie za wyjątkiem jednej - kościoła wybudowanego na terenie pola sejmowego $\mathrm{z}$ materiałów podarowanych na ten cel przez norweskich władców - powstały z prywatnej inicjatywy i na prywatny koszt właścicieli gruntów, na których je postawiono. Część badaczy upatruje w tym względzie inspiracji niemiecką instytucją Eigenkirchenwesen (ecclesia propria) ${ }^{39}$, z którą pierwsi islandzcy kapłani w tym zwłaszcza biskup Îsleif mieli zapoznać się w trakcie pobierania nauk w Saksonii ${ }^{40}$, wydaje się jednak, iż zwyczaj ten jest raczej wyrazem lokalnych warunków instytucjonalnych niż świadomej adopcji obcych rozwiązań. Przy braku scentralizowanego aparatu państwowego instytucje kościelne mogły na Islandii rozwijać się wyłącznie oddolnie ${ }^{41}$.

Średniowieczne islandzkie źródła narracyjne zawierają informacje na temat czterech prywatnych kościołów, które miały powstać tuż po oficjalnym przyjęciu przez Islandczyków chrześcijaństwa oraz około trzydziestu dalszych, które miały zostać wybudowane w kolejnych dekadach XI wieku ${ }^{42}$. Według tradycji utrwalonej w Eyrbyggja saga powodem ich wznoszenia była obietnica, „uzyskania przez ich fundatorów tylu miejsc w Niebie, ile było miejsc stojących w wybudowanych przez nich kościołach" (rozdz. 49) ${ }^{43}$. Współcześni badacze wskazują jednak na kilka dodatkowych bodźców, które mogły wpływać na decyzję gospodarzy o wybudowaniu na swych terenach prywatnej świątyni.

\footnotetext{
${ }^{38}$ J.L. Byоск, Medieval Iceland: Society, Sagas, and Power, Berkeley 1988, s. 148-150.

${ }^{39}$ S. Wood, The Proprietary Church in the Medieval West, Oxford 2009, passim.

${ }^{40}$ G. Karlsson, Iceland's 1100 Years. History of a Marginal Society, London 2000, s. 39.

${ }^{41}$ J.L. Byock, Governmental Order..., s. 33-34.

${ }^{42}$ O. Vésteinsson, The Christianization..., s. 37.

${ }^{43}$ Eyrbyggja saga. Íslenzk fornrit IV, red. G. Jónsson, Reykjavík 1936.
} 
Badania archeologiczne wykazują, iż najstarsze islandzkie kościoły były lokowane w bardzo bliskiej odległości od zagród, a w ich bezpośrednim sąsiedztwie chowano zmarłych, co jednoznacznie sugeruje, iż jednym z głównych celów ich wznoszenia było względy związane z ceremoniami pogrzebowymi i oddawaniem szacunku zmarłym członkom rodziny ${ }^{44}$. Za tezą tą przemawiają też rozmiary przydomowych kościołów (heimiliskirkjur). Większość z nich jest bardzo mała, ich powierzchnia użytkowa zazwyczaj nie przekracza kilkunastu metrów kwadratowych, stąd też jest mało prawdopodobne by mogły się w nich gromadzić osoby spoza gospodarstwa.

Część autorów wskazuje również na fakt, iż w zachowanych źródłach narracyjnych, w tym zwłaszcza dotyczących schyłkowego okresu funkcjonowania bjóðveldið, gdy Islandia miała stać się areną dla zbrojnych starć najpotężniejszych lokalnych rodów, znajdują się liczne przekazy na temat wykorzystywania prywatnych kościołów jako schronienia przed atakami (zob. np. Guðmundar saga dýra, rozdz. 18, 23; Porgils saga skarða, rozdz. 46; Svínfellinga saga, rozdz. 6). Nie jest jednak pewne, czy funkcja ta była znana XI-wiecznym Islandczykom, ergo czy mogła ona być powodem wznoszenia przez nich świątyń. Niektóre skandynawskie źródła dotyczące okresu przedchrześcijańskiego sugerują, iż pogańskie sanktuaria były miejscami, w których każdy łącznie z przestępcami korzystał z nietykalności cielesnej $^{45}$, co może sugerować, iż późniejsza praktyka była przedłużeniem utrwalonej tradycji. Stare Prawa Chrześcijańskie nie zawierają jednakże żadnych informacji dotyczących ochrony, z jakiej miałyby korzystać osoby przebywające na terenie świątyń. $Z$ treści zachowanych źródeł wynika natomiast, iż do połowy XII wieku do islandzkich kościołów swobodnie wnoszono broń (wbrew wyraźnemu

\footnotetext{
${ }^{44}$ Zob. np. G. Zö̈ga, R. Traustadóttir, Keldudalur - A Sacred Place in Pagan and Christian Times in Iceland, w: Cultural Interaction Between East and West. Archaeology, Artefacts and Human Contacts in Northern Europe, red. U. Fransson, Stockholm 2007, s. 225-230.

${ }^{45}$ S. BRINK, Law and Legal Customs in Viking Age Scandinavia, w: Scandinavians from the Vendel Period to the Tenth Century, red. J. Jesch, San Marino 2002, s. 93-96.
} 
zakazowi przewidzianemu w prawie, GII $263_{232}$ ), a naruszenia miru kościelnego były jednym z tematów podjętych w liście wystosowanym do Islandczyków przez Arcybiskupa Niðaróss Eysteinna Erlendssona (pełniącego ten urząd w latach 1161-1188) ${ }^{46}$. Na podstawie wyników badań archeologicznych można natomiast stwierdzić, iż w XIII wieku, w okresie narastającego konfliktu wewnętrznego, stosunkowo częstą praktyką wśród zamożnych Islandczyków było przenoszenie kościołów leżących poza zagrodami w bezpośrednie sąsiedztwo budynków mieszkalnych, tak by korzystające $z$ nich osoby mogły w razie potrzeby jak najszybciej w nich się schronić przed atakami ${ }^{47}$.

W pierwszych dekadach po konwersji właściciele przydomowych kościołów zarządzali nimi w ten sam sposób, co innymi należącymi do nich budynkami. Na przełomie XI i XII wieku normą stało się jednakże wydzielanie z majątku fundatorów pewnej części gruntów, inwentarzu oraz służebności celem zabezpieczenia środków na pokrycie kosztów bieżącego funkcjonowania heimiliskirkjur (opłacenia mszy, zakupu utensyliów liturgicznych, chleba i wina eucharystycznego, etc). Z treści zachowanych prywatnych zbiorów staroislandzkiego prawa wynika, iż około 1200 roku dokonanie odpowiedniej donacji stało się jednym z warunków konsekracji kościoła przez biskupa $\left(G I 4_{31}\right)$. W późniejszym okresie wielkość majątku, jaką gospodarz przekazywał na rzecz wybudowanego przez siebie kościoła stała się podstawą rozróżnienia na tzw. boendakirkjur (l. poj. boendakirkja) i staðir (l. poj. staðr).

Pierwszym mianem - dosłownie „kościół gospodarza” - określano świątynie, na rzecz których dokonano donacji gruntów, których eksploatacja pozwalała na pokrycie co roku kosztów odprawienia prawnie określonego minimum mszy (patrz niżej), ale zbyt małych, by mogły one stanowić samowystarczalne pod względem ekonomicznym gospodarstwa. Drugiego z wyżej wymienionych terminów

\footnotetext{
${ }^{46}$ Diplomatarium Islandicum. Íslenzkt fornbréfasafn, tom 1 Reykjavík 1857, s. 291.

${ }^{47}$ H. PORLÁksson, Why Were the 12th Century Staðir Established, w: Church Centres. Church Centres in Iceland and their Parallels in Other Countries, red. H. Porláksson, Reykholt 2005, s. 144-146.
} 
(dosłownie „miejsce” najprawdopodobniej jest to skrót od heilagr staðr stanowiącego tłumaczenie łacińskiego locus religiosus) używano w odniesieniu do tych kościołów, które obdarzono użytkami rolnymi pozwalającymi im na zachowanie całkowitej niezależności finansowej. Kluczowe znaczenie dla powyższego rozróżnienia miała przy tym nie tylko wielkość gruntów przekazanych na rzecz świątyni, ale także ich położenie. By kościół mógł uchodzić za staðr musiał dysponować więcej niż połową gospodarstwa, na terenie którego został wzniesiony (heimaland). Świątynie, na rzecz których dokonano darowizny gruntów leżących w innym niż one rejonie kraju (útlönd) niezależnie od ich wielkości uznawano za bæendakirkjur ${ }^{48}$.

Zgodnie z normami zawartymi w Sekcji Praw Chrześcijańskich Grágás wszelkie donacje na rzecz kościoła, niezależnie czy miały one formę gruntów, interwenta, czy służebności, miały zostać spisane w akcie donacyjnym (máldagi, l. mnoga máldagar), który miał być publicznie odczytany bądź to przed wiecem lokalnym, do którego należał właściciel, bądź też w trakcie spotkania Zgromadzenia Powszechnego (Alpingi), a następnie ogłaszany raz na dwanaście miesięcy uczęszczającym do niego wiernym podczas obchodów rocznicy jego konsekracji ( $G I 3_{32-33}$ ).

Nominalnym właścicielem gruntów przekazanych w darze kościołowi był święty, którego imię mu nadano (zob. np. Porgils saga skarða, rozdz. 43), w praktyce jednak kontrolę (forráð) nad nimi sprawował kolator i jego spadkobiercy, o czym świadczy treść najstarszych zachowanych aktów donacyjnych. Dla przykładu w máldagi z 1170 roku ustanawiającym staðr na majątku Húsafell w Borgarförður znajduje się następujący zapis: „Brandr Pórarinsson [kolator] będzie nadzorował majątek należący do tego kościoła tak długo jak zechce, a później

\footnotetext{
${ }^{48}$ Dla przykładu, jeśli bogaty gospodarz był właścicielem trzech farm A, B i C położonych w różnych częściach wyspy i przy farmie A wybudował kościół, to mógł z niego uczynić staðr tylko, jeśli przekazał na jego rzecz więcej niż połowę gruntów stanowiących część farmy A. Gdyby dokonał na jego rzecz donacji farmy B i/lub C, kościół ten byłby uznany za boendakirkjur, nawet gdyby te ostatnie były większe/bardziej dochodowe niż farma A.
} 
jego synowie, tak długo jak będą sobie tego życzyli. Jeśli zdecydują się oni na jego opuszczenie mają wyznaczyć zarządce, gdyby zaś nie mieli spadkobiercy, który mógłby sprawować kontrolę [nad majątkiem kościoła], jego zarządcą ma zostać ktoś z ich rodziny, kogo biskup [diecezji] Skálholt uzna za stosownego"49.

Zgodnie z normami zawartymi w Sekcji Praw Chrześcijańskich przywłaszczenie majątku przekazanego na rzecz kościoła przez osoby trzecie zagrożone było karą trzyletniej banicji $\left(G I 3_{32-33}\right)$. Ponadto z treści Grágás wynika, iż budynek kościelny i wszelkie mienie ruchome znajdujące się na jego wyposażeniu miało pozostawać pod kontrolą kolatora nawet jeśli nie były one już wykorzystywane do celów sakralnych. Przeniesienie praw do nich możliwe było wyłącznie jeśli osoba, która sfinansowała jego budowę, wyraziła na to zgodę (taką zgodę musiał również wyrazić biskup, a jeśli kościół został wzniesiony na gruntach należących do kogoś innego niż kolator - z zachowanych aktów donacyjnych wynika, iż niekiedy finansowały je całe rodziny także i ich właściciel; $\left.G I 5_{36}\right)$.

W oparciu o analizę około 130 zachowanych aktów donacyjnych z XII i XIII wieku, istnieje możliwość podzielenia islandzkich kościołów z tego okresu na trzy zasadnicze kategorie - kościoły parafialne (sóknarkirkjur, l. poj. sóknarkirka), filialne (útkikjur, l. poj. útkirkja) i kaplice (bænhús, l poj. tak samo) ${ }^{50}$. Mianem sóknarkirkjur określano kościoły, z którymi na stałe związany był co najmniej jeden ksiądz, w których w każdą niedzielę oraz inne dni świąteczne nakazane odbywały się msze i przy którym istniała kongregacja wiernych wykraczająca poza mieszkańców jednego gospodarstwa. Do útkikjur zaliczano z kolei wszystkie kościoły, z którymi nie był związany żaden ksiądz, ale w których regularnie odbywały się msze. W zależności od ilości tych ostatnich kościoły filialne były dzielone na Islandii na pełne, połowiczne i ćwiartkowe, odpowiednio: alkikjur, hálfkikjur i fórdungskikjur. Kaplicami z kolei w aktach donacyjnych określane są wolnostojące budowle sakralne, o statusie niższym niż hálfkikjur,

\footnotetext{
${ }^{49}$ Diplomatarium Islandicum..., tom 1, s. 217-218.

${ }^{50}$ O. VÉsteinsson, The Christianization..., s. 112-143.
} 
w których liturgie odbywały się nieregularnie. Máldagi dotyczące bœenhús zawierają wszelako wskazanie minimalnej ilości mszy, które mają w nich zostać odprawione każdego roku (zwykle 12 per annum).

Nie dysponujemy obecnie informacjami, które pozwoliłyby na ustalenie pełnej liczby kościołów wybudowanych na Islandii przed upadkiem Pjóðveldið, nie mniej jednak większość badaczy skłania się ku tezie, iż wzniesiono je praktycznie przy każdym gospodarstwie, które było stać na poniesienie wydatku związanego z ich wybudowaniem i utrzymaniem ${ }^{51}$ - minimum przy co trzeciej farmie ${ }^{52}$. $Z$ informacji zawartych w Páls saga biskups (rozdz. 11) wynika natomiast, iż około 1200 roku na terenie Południowej, Wschodniej i Zachodniej Kwarty funkcjonowało łącznie 220 sóknarkirkjur. Według szacunków badaczy tym samym czasie w Kwarcie Północnej kościołów parafialnych było około $115^{53}$.

$\mathrm{Na}$ podstawie analizy źródeł narracyjnych oraz zachowanych aktów donacyjnych szacuje się, iż na około 335 kościołów parafialnych funkcjonujących na Islandii w początku XIII wieku 115 stanowiło staðir, 220 beendakirkjur ${ }^{54}$. W drodze wstecznej ekstrapolacji zapisów z XIV wieku możliwe jest również ustalenie, iż dla ich obsłużenia niezbędnych było około 400 księży ${ }^{55}$. Osiągnięcie takiego stanu osobowego musiało być jednak wynikiem długiego i bardzo powolnego procesu, albowiem aż do ostatnich dekad XI wieku Islandczycy nie dysponowali wieloma sposobnościami do przyjęcia święceń kapłańskich.

${ }^{51}$ B. Eyıórsson, History of the Icelandic Church 1000-1300. Status Of Research, w: Church Centres..., s. 21 i przywoływane tam pozycje literatury przedmiotu.

${ }^{52}$ O. Vésteinsson, The Christianization..., s. 55.

${ }^{53}$ J.V. SigurĐsson, Chieftains and Power in the Icelandic Commonwealth, Odense 1999, s. 107.

${ }^{54}$ Tamże, s. 107.

${ }^{55}$ H.S. KJartansson, Thin on the Ground. Legal Evidence of the Availability of Priests in the 12th Century Iceland, w: Church Centres..., s. 95. 


\section{Wczesne islandzkie duchowieństwo}

Kristni saga (rozdz. 12) zawiera informacje o księdzu o imieniu Pormóðr oraz siedmiu innych niezidentyfikowanych bliżej osobach w szatach liturgicznych (skýrddur), które miały być obecne przy tym jak Gizurr Biały i Hjalti Skeggjason ogłaszali ze Skały Prawa misję jaką obarczył ich król Óláf Tryggvason. Z treści staroislandzkich źródeł wynika również, iż początkiem panowania w Norwegii Óláfa II Haraldssona (po $1015 \mathrm{roku}$ ), na Islandii zaczęli pojawiać się niemieccy i angielscy biskupi misyjni. Według tradycji utrwalonej przez Ariego fróði w Îslendingabók (rozdz. 8) miało być ich sześciu - Bjarnharðr, Kolr, Hróðólfr, Jóhan, Bjarnharðr i Heinrekr. Ponadto autor Ksieggi Islandczyków wymienia imiona pięciu kolejnych biskupów mających prowadzić na Islandii działalność misyjną już w czasach posługi biskupiej Îsleifa Gizurarsona, lecz nie uznawanych przez Kościół Katolicki - Örnólfa, Goðiskálka, oraz „trzech z Ermland” (w oryginale prír ermskir, najprawdopodobniej pod pojęciem tym kryje się Warmia) Piotra, Abrahama i Stefana. Z zachowanych źródeł narracyjnych wynika zatem, iż do połowy XI wieku na Islandii funkcje kapłańskie pełniło jednocześnie nie więcej niż kilka, maksymalnie kilkanaście osób będących w większości najprawdopodobniej obcokrajowcami.

Przełomowym momentem $\mathrm{w}$ historii islandzkiego kościoła był dzień 26 maja 1056, kiedy to arcybiskup Hamburga-Bremen Adalbert nadał sakrę biskupią Ísleifowi Gizurarsonowi, nominowanemu na urząd biskupi przez Papieża Leona IX (Hungrvaka, rozdz. 2; Íslendingabók, rozdz. 14). Nie wiemy w jaki sposób dokonano wskazania Ísleifa na pierwszego rodzimego biskupa Islandii. Ari milczy na ten temat, zaś późniejsze staroislandzkie źródła, których autorzy sugerują, iż stało się to w drodze jakiejś formy elekcji (Hungrvaka, rozdz. 2; Kristni saga, rozdz. 14), nie są uznawane przez współczesnych badaczy za wiarygodne, z uwagi na zbyt długi okres dzielący ich spisanie od relacjonowanych w nich wydarzeń. Nadto w literaturze przedmiotu podkreśla się, iż aż do połowy XII wieku wszyscy kolejni islandzcy biskupi byli związani z jednym $\mathrm{z}$ najpotężniejszych lokalnych rodów Haukdælir i nie wydaje się by wystawiani przezeń kandydaci mieli 
jakichkolwiek konkurentów ${ }^{56}$.Zdaniem Orriego Vésteinssona dopiero po 1150 roku możemy zasadnie mówić o przeprowadzaniu na Islandii wyborów biskupich, jednakże także i w ich przypadku szczegóły procedur elekcyjnych nie są nam znane ${ }^{57}$.

Zachowane kopie Grágás nie zawierają żadnych informacji na ten temat wyłaniania biskupów elektów. W oparciu o analizę treści źródeł narracyjnych możemy wszelako domniemywać, iż gdy któryś z dwóch islandzkich biskupów zmarł lub utracił zdolność do wykonywania posługi z powodów zdrowotnych, mieszkańcy kwart znajdujących się na terenie danej diecezji (trzech w przypadku Skálholt, jednej w przypadku Hólar - patrz niżej) wskazywali po jednym kandydacie na kwartę, spośród których następnie podczas dorocznej sesji Zgromadzenia Powszechnego wybierany był jeden electus. Przed przedstawieniem go arcybiskupowi do wyświęcenia musiał on jednak uzyskać akceptację drugiego z islandzkich biskupów (zob. zwł. Porláks saga byskups, rozdz. 9).

Powyższa procedura znacznie odbiega od standardów prawa kanonicznego, w ramach którego od 1139 roku, tj. od Drugiego Soboru Laterańskiego, w wyborach biskupa elekta mieli brać udział wyłącznie kanonicy z kapituł katedralnych (na Islandii pierwszą z nich powołano dopiero w 1267 roku, już po upadku Pjóðveldið ${ }^{58}$ ). Procedury elekcyjne nie były w tym względzie jedynymi islandzkimi odstępstwami od norm prawa kanonicznego. Wśród biskupów elektów znajdowały się osoby pozostające w związkach małżeńskich, zrodzone z nieprawego łoża, a nawet jeden electus nie mający święceń kapłańskich (Páll Jónsson, biskup Skálholt w latach 1195-1211). Mimo to, aż do 1237 roku każdy islandzki biskup elekt otrzymał sakrę biskupią $\mathrm{z}$ rąk odpowiedniego arcybiskupa (początkowo Hamburga-Bremy, od 1104 roku duńskiego Lund, zaś po 1153 roku norweskiego Niðaróss).

W okresie funkcjonowania Pjóðveldið organizacja islandzkiego kościoła była bardzo rudymentarna. Jedynymi wyraźnie

\footnotetext{
${ }^{56}$ O. VÉsteinsson, The Christianization..., s. 144.

${ }^{57}$ Tamże, s. 147-148.

${ }^{58}$ J.L. Вуоск, Medieval..., s. 157.
} 
wyodrębnionymi jednostkami administracyjnymi były dwie diecezje Skálholt i Hólar. Ich granice pokrywały się z dokonanym około 965 roku podziałem administracyjnym kraju na cztery kwarty (fórðung). Diecezja Skálholt obejmowała swymi granicami cały teren kwarty Południowej, Wschodniej i Zachodniej, zaś Hólar kwartę Północną (GI $\left.5_{35-36}\right)$. Funkcjonujące w ich ramach parafie (sóknir, 1. poj. sókn), aż do XIV wieku miały raczej personalny, niż terytorialny charakter i znamionowały grupę wiernych, którzy uiszczali dziesięcinę na rzecz tego samego kościoła parafialnego (patrz kolejny punkt) ${ }^{59}$.

Ísleifr Gizurarson podobnie, jak jego zagraniczni poprzednicy wymieniani przez Ariego, był jedynie biskupem in partibus infidelium. Pierwsza islandzka diecezja została utworzona dopiero $\mathrm{z}$ inicjatywy jego syna Gizurra, który przyjął sakrę biskupią w 1082 roku w Magdeburgu z rąk arcybiskupa Hartwiga (Hungrvaka, rozdz. 4). Dla sfinansowania jej działalności miał on przekazać na rzecz Kościoła odziedziczony po ojcu majątek Skálholt, tradycyjnie uznawany za pierwszy staðr. Nie wiemy kiedy dokładnie nastąpiło formalne utworzenie pierwszego biskupstwa rezydencjonalnego na Islandii, z zachowanych źródeł narracyjnych wdaje się jednak wynikać, iż stało się to już po wprowadzeniu w 1097 roku dziesięciny (Íslendingabók, rozdz. 10, Kristni saga, rozdz. 15-16).

Druga $z$ islandzkich diecezji Hólar miała wedle relacji Ariego fróði powstać „kiedy [biskup Gizurr] uznał, iż biskupstwo [Skálholt] stało się dostatecznie bogate" (anonimowy autor kroniki biskupstwa Skálholt szacuje, iż miało to miejsce w około dwadzieścia lat od odebrania przez Gizurra sakry biskupiej, czyli c. 1102 roku, Hungrvaka, rozdz. 4). Wydzielił on wówczas ze swojej diecezji „przeszło jedną czwartą [terytorium], tak by w tym kraju funkcjonowały dwa biskupstwa a nie jedno, o co prosili go mieszkańcy Północnej Kwarty" (Íslendingabók, rozdz. 10). Na siedzibę drugiej z islandzkich diecezji wybrano majątek Hólar í Hjaltadal, przekazany na ten cel przez jednego z pierwszych islandzkich księży Illugi Bjarnasona. Pierwszą osobą, która objęła urząd biskupa w nowo utworzonej Diecezji

${ }^{59}$ B. Eypórsson, History..., s. 65. 
Północnej był konsekrowany w 1106 roku w Lund Jón Ögmundsson, zwany przez Islandczyków Świętym ${ }^{60}$.

Z zachowanych źródeł narracyjnych wynika, iż jednym z głównych zadań jakie postawili sobie pierwsi islandzcy biskupi było kształcenie lokalnych księży. Zgodnie z przekazem zawartym w Íslendingabók, wkrótce po udzieleniu mu sakry biskupiej Ísleif ustanowił na swojej farmie w Skálholt (wówczas będącej jedynie rodzinnym gospodarstwem) szkołę, do której swych synów posłali członkowie najpotężniejszych islandzkich rodów. Trzech z uczniów Ísleifa odebrało później święcenia biskupie: jego syn Gizzur, Jón Ögmundsson oraz Kollr Porkelsson, który wedle relacji Ariego fróði miał być biskupem w norweskim Vík (Íslendingabók, rozdz. 9). Święcenia kapłańskie miał również przyjąć drugi z synów Îsleifa Teitr, na którego relacjach opierała się w znacznej mierze Księga Islandczyków.

Według tradycji spisanej w Kristni saga, Gizurr Îsleifsson kontynuował misję swego ojca na tyle skutecznie, iż za jego posługi biskupiej (1082-1118) „większość mężczyzn o wysokim statusie odebrała [od niego] edukację i przyjęła święcenia kapłańskie i to nawet pomimo tego, że byli oni wodzami" (Kristni saga, rozdz. 17). Dla potwierdzenia tego faktu, anonimowy autor przytaczanej kroniki wymienia z imienia dziesięciu wodzów, którzy za episkopatu Gizurra zostali duchownymi (a wśród nich Ariego fróði), zaznaczając wszelako, iż było ich wiele więcej. Fakt przyjęcia święceń kapłańskich przez większość islandzkich wodzów potwierdza również lista czterdziestu szlachetnie urodzonych księży (po dziesięciu na ćwiartkę) pochodząca $\mathrm{z} 1143 \mathrm{roku}^{61}$.

Powyższe przekazy, jak i inne komplementarne wobec nich źródła narracyjne, sugerują, iż najpóźniej w pierwszej połowie XII wieku

\footnotetext{
${ }^{60} \mathrm{~W}$ świetle adnotacji dokonanej w annałach biskupstwa Skálholt, w 1200 roku Jón został ogłoszony na Islandii lokalnym świętym (Islandske Annaler indtil 1578, red. G. Storm, Christiania 1888, s. 181). Jedynym oficjalnie uznanym przez Stolicę Apostolską katolickim świętym pozostaje wszelako Porlákr Pórhallsson, biskup Skálholt w latach 1178-1193, kanonizowany przez Papieża Jana Pawła II 14 stycznia 1984 roku.
}

${ }^{61}$ Diplomatarium Islandicum..., tom 1, s. 185-186. 
standardem stało się na Islandii łączenie funkcji katolickiego duchownego z funkcją świeckiego wodza ${ }^{62}$. Część współczesnych autorów uważa tę prawidłowość za naturalną kontynuację sytuacji sprzed konwersji religijnej, kiedy to według późnośredniowiecznych źródeł goðar mieli przewodzić pogańskim ceremoniom kultowym ${ }^{63}$. Inni uznają ją za nowy trend będący wynikiem chęci wzmocnienia przez wodzów swojej pozycji vis á vis wolnych gospodarzy (boendr) oraz tych spośród lokalnych liderów, których autorytet miał wyłącznie świecki charakter ${ }^{64}$.

Zachowane kopie Grágás nie zawierają żadnych norm dotyczących księży będących jednocześnie wodzami (we współczesnej literaturze przedmiotu powszechnie określanych mianem kirkjugoðar). Brak odpowiednich regulacji może być powodowany dwoma przyczynami. Nie mamy pewności kiedy dokładnie zostały spisane normy zachowane w znanej nam wersji Sekcji Praw Chrześcijańskich (oryginalna, pochodząca z okresu 1122-1133 kopia Kristinna laga páttr zaginęła), jednak większość badaczy skłania się ku tezie, iż stało się to między 1199 a 1217 rokiem $^{65}$. W omawianym tu kontekście jest to o tyle istotne, iż w 1190 roku Arcybiskup Erik Ivarsson zabronił islandzkim biskupom udzielania święceń kapłańskich wodzom. Może to oznaczać, iż w momencie spisywania zachowanej wersji Starych Praw Chrześcijańskich normy odnoszące się do kirkjugoðar pominięto z uwagi na utratę przez nich mocy obowiązującej. Możliwe jest jednak również to, iż takowe normy nigdy nie istniały. Zważywszy na pozycję wodzów w islandzkiej hierarchii społecznej jest mało prawdopodobne, by pełnili oni posługę kapłańską poza należącymi do nich świątyniami i szczególnymi okazjami pozwalającymi im na zamanifestowanie swojego statusu - np. ślubów arystokratycznych

\footnotetext{
${ }^{62}$ O. Vésteinsson, The Christianization..., s. 182-194.

${ }^{63}$ G. Turville-Petre, E.S. Olszewska, The Life of Gudmund the Good, Bishop of Holar, Coventry 1942, s. XI; J.V. SigurĐsson, Chieftains..., s. 185-188; G. KARLsson, Iceland's 1100 Years. History of a Marginal Society, London 2000, s. 40.

${ }^{64}$ O. Vésteinsson, The Christianization..., s. 7-8.

65 Tamże, s. 195.
} 
par, chrzcin wysoko urodzonych dzieci, itp. Większość obowiązków związanych z bieżącym funkcjonowaniem wspólnoty wiernych - celebrowaniem zwykłych niedziel roku liturgicznego, namaszczaniem chorych, pochówkiem zmarłych, etc. spoczywała zapewne na tzw. księżach parafialnych (pingaprestar, l. poj. pingaprestr) wywodzących się w większości z niższych warstw społecznych i to właśnie na ich prawach i obowiązkach skupiają się redaktorzy zachowanych kopii Kristinna laga páttr Grágás.

Zdaniem historyków islandzkiego kościoła grupa pingaprestar wykształciła się, bądź też wyraźnie przybrała na liczebności w rezultacie wprowadzenia pod koniec XI wieku dziesięciny (tíund, patrz kolejny punkt ${ }^{66}$. Zgodnie z przyjętymi wówczas normami kolator świątyni, który chciał mieć swój udział w dziesięcinie był zobowiązany do odprawienia w niej dziesięciu mszy rocznie, a jeśli sam był księdzem - trzynastu $\left(G I \ddagger 7_{199}\right)$. Liczba kirkjugoðar z całą pewnością nie wystarczyła do zaspokojenia potrzeb właścicieli heimiliskirkjur, można też mieć wątpliwości, czy byliby oni skłonni podróżować pomiędzy znacznie oddalonymi od siebie małymi, przydomowymi kościołami i posługiwać wiernym o niższym (często znacznie) statusie społecznym. Z analiz dokonanych przez Helgi Skúli Kjartanssona wynika wszelako, iż dziesięcina pobrana od mieszkańców kilku gospodarstw z powodzeniem wystarczyła do pokrycia kosztów posługi jednego pingaprestr ${ }^{67}$.

Zgodnie z normami zawartymi w Grágás status prawny pingaprestar był zbliżony do wykwalifikowanych pracowników najemnych, np. szkutników, czy bednarzy (GI 6 $37-38$. Byli oni zatrudniani przez gospodarzy będącymi kolatorami kościołów parafialnych na roczne umowy, zaś w zamian za pracę duszpasterską mieli oni otrzymywać wikt i opierunek (GI $3_{33}$ ), a nadto wynagrodzenie w maksymalnej wysokości 12 marek per annum (do powyższej kwoty nie wliczano opłat za ceremonie pogrzebowe, GI $2_{27}$ ). Jeśli zabiegali o otrzymanie wyższej kwoty podlegali karze trzech marek grzywny

\footnotetext{
${ }^{66}$ H.S. KJartansson, Thin...5, s. 100-102.

${ }^{67}$ Tamże, s. 101.
} 
$\left(G I 6_{37}\right)$. W trakcie trwania umowy, pingaprestar byli traktowani przez przyjmującego ich gospodarza jak służba domowa ( $g r i ð m e n n$, r.ż. griðkonur), z tym zastrzeżeniem iż w przeciwieństwie do członków tej ostatniej nie otrzymywali oni wynagrodzenia w stałej z góry określonej przez prawo wysokości, lecz w zależności od liczby wykonywanych czynności liturgicznych oraz nie mogli być kierowani do prac gospodarskich.

Księża parafialni mieli być posłuszni biskupowi, okazywać mu na żądanie swe księgi i przedmioty liturgiczne, co najmniej raz w miesiącu golić zarost i strzyc tonsurę oraz powstrzymywać się od noszenia niestosownych ubiorów. Za naruszenie tych norm odpowiadali przed specjalnym sądem działającym przy Zgromadzeniu Powszechnym, którego skład orzekający tworzyło dwunastu duchownych nominowanych ad hoc przez biskupa dla danej diecezji. W razie uznania ich winnymi ponosili oni karę w wysokości 3 marek grzywny $\left(G I 6_{37-38}\right.$; $\mathrm{GI} \ddagger 9_{200}$, za naruszenia norm świeckich odpowiadali oni przed sądami wiecowymi na takich samych zasadach jak przedstawiciele laikatu). Zachowane kopie Grágás nie zawierają natomiast informacji na temat ich obowiązków wobec wiernych. Redaktorzy znanych kopii Sekcji Praw Chrześcijańskich stwierdzają jedynie, iż pingaprestar musieli być zawsze dostępni celem przeprowadzenia chrzcin i że jeśli opuszczali gospodarstwo, stanowiące ich prawny domicyl na noc lub dłużej, to musieli mieć przy sobie wszystkie przedmioty liturgiczne niezbędne do udzielenia tego sakramentu ( $G I \ddagger 1_{197}, G I \ddagger 4_{197}$ ). Jeśli rodzice nowonarodzonego dziecka nie mogli ich odnaleźć podlegali oni karze trzyletniej banicji. Taką samą karę staroislandzkie prawo przewidywało za odmowę przeprowadzenia chrztu $\left(G I 1_{23}\right)$ oraz ujawnienie treści spowiedzi $\left(G I \ddagger 9_{200}\right)$. Ponadto księża parafialni mieli odprawiać liturgie pogrzebowe, namaszczać chorych, przyjmować spowiedzi i błogosławić szczątki ekshumowane w związku z przeniesieniem cmentarza $\left(G I 2_{28}\right)$. Za uchylanie się przez nich od tych czynności islandzkie prawo nie przewidywało jednak żadnych kar.

Normy zawarte w zachowanych kopiach Kristinna laga páttr zabraniają księżom parafialnym odprawiania więcej niż dwóch mszy dziennie oraz celebrowania mszy nocnych (za wyjątkiem Wigilii 
Bożego Narodzenia, GI $6_{37}$ ). W połączeniu z wymogiem finansowania wyłącznie dziesięciu mszy rocznie przez kolatorów kościołów nie będących księżmi regulacje te sugerują, iż jeszcze z końcem XII wieku, kiedy spisano znaną nam wersję Starych Praw Chrześcijańskich, islandzki kościół borykał się z poważnymi brakami kadrowymi ${ }^{68}$. Problemowi temu miało zaradzić powołanie trzeciej kategorii księży, tzw. heimilisprestar (1. poj. heimilisprestr, dosłownie „ksiądz domowy”), których status społeczny porównywany jest niekiedy w literaturze do statusu niewolników ${ }^{69}$.

Grágás przyznawało kolatorom kościołów prawo do zawierania umów z nastoletnimi chłopcami (jeśli przekroczyli 16 rok życia osobiście, jeśli byli młodsi za pośrednictwem ich opiekunów prawnych), na mocy których zobowiązywali się oni do pokrycia wszelkich kosztów przysposobienia ich do pełnienia posługi duszpasterskiej, w zamian za co ci ostatni mieli po odebraniu święceń kapłańskich do końca swego życia odprawiać na ich rzecz co roku prawnie określoną liczbę mszy $\left(G I 4_{34}\right)$. Z obowiązku tego byli zwalniani wyłącznie jeśli znaleźli chłopców, którzy zgodzili się ich zastąpić a następnie wykształcili ich w satysfakcjonujący lokalnego biskupa sposób lub gdy pełnienie posługi uniemożliwiał im stan zdrowia $\left(G I 4_{35}\right)$. Jeśli „ksiądz domowy” bez zezwolenia swego patrona opuścił jego gospodarstwo, traktowano go, jak osobę wyjętą spod prawa. Zbiegłym heimilisprestar nie wolno było udzielać jakiejkolwiek pomocy i schronienia, ani uczestniczyć w prowadzonych przez nich liturgiach. Każdy z tych czynów zagrożony był karą pełnej banicji (GI $4_{35}$ w związku z $\left.G I 4_{84}\right)$. Taki ksiądz mógł też zostać siłą doprowadzony do właściciela kościoła, z którym pozostawał związany umową, a w okresie przysposobienia do pełnienia posługi duszpasterskiej karcony fizycznie, „tak jednak by nie doznał trwałego uszczerbku na zdrowiu” (GI $\left.4_{34}\right)$. Jeśli heimilisprestr zmarł w trakcie trwania umowy wszelki jego majątek o wartości nieprzekraczającej 360 łokci samodziału (wełniana tkanina pełniąca

\footnotetext{
${ }^{68}$ B. Eypórsson, History..., s. 22.

${ }^{69}$ J. JóH AnNesson, Íslendinga..., s. 166.
} 
role pieniądza towarowego) podlegał dziedziczeniu przez kolatora kościoła, z którym był on związany $\left(G I 4_{35}\right)$.

\section{Wprowadzenie dziesięciny}

Przez niemal wiek od konwersji Islandczyków działalność księży była najprawdopodobniej w całości finansowana z prywatnych środków kolatorów oraz opłat za czynności liturgiczne. Wprawdzie część staroislandzkich źródeł narracyjnych zawiera informacje sugerujące, iż jeszcze w czasach przedchrześcijańskich na Islandii pobierano opłatę świątynną (hoftollar, zob. np. Eyrbyggja saga, rozdz. 4), która wkrótce po konwersji miała zostać przekształcona z prywatnej inicjatywy wodzów na swoisty podatek kościelny, jednak większość współczesnych badaczy uznaje te przekazy za anachroniczne ${ }^{70}$. W sadze poświęconej pierwszemu islandzkiemu biskupowi (Ísleifs páttr biskups) znajdują się dodatkowo informacje o specjalnej opłacie eklezjalnej jaką miał pobierać Ísleif Gizurarson, jednak nawet jeśli ona rzeczywiście funkcjonowała, co do czego można mieć wątpliwości, to musiała ona być zbyt mała w stosunku do potrzeb, gdyż jak czytamy w kronice diecezji Skalhólt „przychody [biskupa] były małe, wydatki zaś wielkie” (Hungrvaka, rozdz. 2).

Do zmiany tej sytuacji miał doprowadzić dopiero biskup Gizurr Ísleifsson, który działając w porozumieniu z Głosicielem Prawa Markúsem Skeggjasonem (pełniącym tą funkcję w latach 1084-1107) zdołał przekonać członków Zgromadzenia Prawodawczego (Lögrétta) do przegłosowania w 1097 roku uchwały wprowadzającej na Islandii obowiązkową dziesięcinę (tíund). Według przekazów utrwalonych w Íslendingabók, jej przyjęcie miało być wyrazem niezwykłego szacunku jakim biskup cieszył się wśród swoich rodaków. „Biskup Gizurr był bardziej popularny, niż jakakolwiek inna osoba [na Islandii]. (...) Jest znakiem wielkiego posłuszeństwa jakie ludzie w tym kraju okazali temu człowiekowi, że udało mu się doprowadzić by wszelka własność na Islandii, włączając w to ziemię, została poddana pod przysięgą wycenie i by odprowadzano od niej dziesięcinę i że prawa

${ }^{70}$ O. VÉsteinsson, The Christianization..., s. 75-76. 
na mocy których ją wprowadzono miały obowiązywać, tak długo jak Islandia pozostanie zamieszkaną" (Íslendingabók, rozdz. 10).

Przyjęcie przez Islandczyków prawa o obowiązkowej dziesięcinie było wydarzeniem bez precedensu w krajach skandynawskich, w których próby jej wprowadzenia spotkały się ze zdecydowanym oporem lokalnej społeczności. W Danii, pierwszym kraju normańskim, w którym podjęto próbę jej poboru, inicjatywa ustanowienia daniny na rzecz kościoła doprowadziła do wybuchu rewolty, na skutek której w 1086 roku śmierć poniósł król Kanut IV (ostatecznie zaczęto ją pobierać w 1135 roku). W Norwegii do jej wprowadzenia miał się publicznie zobowiązać w 1110 roku Sigurðr I Jórsalafari (Krzyżowiec) jednak pierwsze niebudzące wątpliwości świadectwa dotyczące jej faktycznego poboru pojawiają się dopiero po 1163 roku za panowania Magnúsa Erlingssona. W Szwecji udało ją się wprowadzić dopiero pod koniec XII wieku.

Burzliwą historię wprowadzania dziesięciny w krajach skandynawskich tłumaczy się zazwyczaj brakiem tradycji pobierania podatków przez lokalnych władców - do czasu jej przeforsowania świadczenia publiczne przybierały w tych krajach formę ponoszenia kosztów wyposażania i/lub osobistego udziału w zbrojnych wyprawach monarchy (tzw. leidang) ${ }^{71}$ - oraz niedostatecznie silną pozycją władz świeckich i biskupich. Ponieważ obie powyższe uwagi odnoszą się w pewnym zakresie także i do Islandii, we współczesnej literaturze przedmiotu podejmowanych jest szereg prób wyjaśnienia, dlaczego to, co przez długi czas nie udawało się skandynawskim władcom, udało się islandzkim goðar i to - jeśli wierzyć zachowanym źródłom - bez istotnego sprzeciwu ze strony wolnych gospodarzy. Zdaniem większości badaczy odpowiedzi na to pytanie należy szukać w cechach przyjętej na wyspie dziesięciny, która w postaci w jakiej ją znamy z Grágás (GII 255-261 221231) pod wieloma względami istotnie odbiega od standardów prawa kanonicznego, istotnie faworyzując przy tym lokalne elity ${ }^{72}$.

\footnotetext{
${ }^{71}$ S. BAGge, Cross..., s. 108-109.

${ }^{72}$ J. JóH Annesson, Íslendinga..., s. 170-178. Własną próbę analizy tego zjawiska podejmuję w artykule Islandzka dziesięcina $w$ świetle teorii grup interesu, Prace Historyczne 146(2019), s. 673-687.
} 
Islandzkie tíund wbrew zwyczajowi rozpowszechnionemu w krajach kontynentalnych nie miało formy dziesiątej części dochodów, lecz maksymalnie jednego procenta wartości wolnego od długu majątku ruchomego i nieruchomego jakim dysponowała dana osoba. Z uwagi na fakt, iż islandzkiej dziesięcinie podlegał także majątek nieożywiony, uznawany za Kościół za per se nieproduktywny, tíund wypełniało wszelkie znamiona lichwy, co wzbudzało wielkie zdumienie obcokrajowców. Faktu tego nie omieszkał wypomnieć Islandczykom, już po utracie przez nich niepodległości na rzecz Norwegii, wysłannik norweskiego monarchy Loðinn leppr, który w 1281 roku miał zwrócić się do biskupa Árni Porlákssona tymi oto słowy: „[co zaś się tyczy lichwy], w pełni zgadzam się, iż jest ona złem i że lichwiarze powinni być ekskomunikowani. Czy jednak lichwa jest bardziej uciążliwa, niż niesprawiedliwy sposób poboru dziesięciny, jaki jest stosowany w tym kraju? Wy [islandzcy] biskupi, żądacie by naliczać dziesięcinę od broszek i srebrnych klamer, pucharów i baryłek oraz innych przedmiotów. Zdumiewa mnie, że mieszkańcy tego kraju tolerują tak oburzające zachowania i zastanawiam się dlaczego nie stosujecie nordyckiej metody pobierania dziesięciny, która przecież jest praktykowana na całym świecie i jest jedyną sprawiedliwą i uznawaną przez prawo [kanoniczne]”. W odpowiedzi na ten zarzut, biskup Árni miał powołać się na opinię papieża Innocentego (nie jest wiadomym, którego z czterech noszących to imię w interesującym nas okresie papieży biskup miał na myśli), który miał potwierdzić, iż islandzki sposób naliczania dziesięciny „nie stanowi zagrożenia dla niczyjej duszy" (Árna saga biskups, rozdz. 29).

Niezależnie od tego, czy tíund rzeczywiście mogło być uznane za lichwę, czy też nie, faktem jest, iż sposób jej poboru był jedynym możliwym do zrealizowania w warunkach islandzkiej gospodarki opartej przede wszystkim na hodowli owiec, bydła i rybołówstwie ${ }^{73}$. Określenie, która z metod obliczania dziesięciny - 10\% dochodów, czy maksymalnie 1\% wolnego od długów majątku - była bardziej uciążliwa pod względem finansowym dla podatników jest praktycz-

\footnotetext{
${ }^{73}$ O. VÉsteinsson, The Christianization..., s. 69-70.
} 
nie niemożliwe, nie ulega natomiast wątpliwości, iż ta druga była znacznie łatwiejsza w stosowaniu i nie wiązała się z problemami, na które często uskarżali się kontynentalni gospodarze, którzy nie mogli zwieść z pola zbiorów do czasu policzenia snopów przez przedstawiciela kościoła, bądź też musieli żywić na własny koszt zwierzęta hodowlane przekazywane kościołowi w naturze do czasu ich odebrania przez osobę wyznaczoną przez biskupa ${ }^{74}$.

Zgodnie z normami zawartymi w Grágás każdy mieszkaniec Islandii powyżej szesnastego roku życia bez względu na płeć, miał podczas jesiennego spotkania właściwej dla niego wspólnoty sąsiedzkiej (hreppr $)^{75}$ publicznie i pod przysięgą wyliczyć wszystkie składniki majątku jakim dysponowali na koniec maja danego roku i podać jego aktualną wartość (GII 255 222 ). Dziesięcinie podlegał cały wolny od długów majątek ruchomy i nieruchomy za wyjątkiem: 1) „własności przeznaczonej ku chwale Boga”, tj. darowizn na rzecz kościoła, a także mostów oraz przepraw rzecznych; 2) szat, ksiąg i przedmiotów liturgicznych należących do księży (wszystkie pozostałe składniki ich majątku podlegały dziesięcinie); 3) zapasów domowych, które pozostały z poprzedniej wiosny; 4) wodzostw ( goðorð), które dla celów tíund traktowano jako „władztwo, nie zaś majątek” (velldi er pat en oeigi fé); 5) oraz w przypadku osób najbiedniejszych - ubrań codziennego użytku (GII 255 221 ).

Jeśli wartość publicznie zadeklarowanego przez daną osobę majątku przekroczyła prawnie określone minimum ustalone na 10 legalnych-uncji (lögaurar, 1. poj. lögeyrir, równowartość 60 łokci

\footnotetext{
${ }^{74}$ J. JóH Annesson, Íslendinga..., s. 172.

${ }^{75}$ Wspólnoty sąsiedzkie (hreppar, 1. poj. hreppr) stanowiły związek co najmniej dwudziestu gospodarstw, których zarządcy (właściciele bądź dzierżawcy) dysponowali prawnie określonym majątkiem. Przynależność do wspólnoty była obowiązkowa, a one same miały charakter terytorialny (GII 234 ${ }_{185}$ ). Hreppar nadzorowały korzystanie ze wspólnych pastwisk, zarządzały systemem ubezpieczeń wzajemnych przed skutkami nieszczęśliwych zdarzeń (np. pożarów, powodzi, pomoru zwierząt gospodarskich) oraz odpowiadały za organizowanie pomocy członkom wspólnoty znajdującym się w trudnej sytuacji.
} 
samodziału, isl. vaðmál) ${ }^{76}$, wówczas musiała ona przeznaczyć określany prawnie procent należących do niej zasobów na cel dziesięciny. Przy tym zgodnie z Grágás najniższe tíund nie mogło być mniejsze niż jeden łokieć samodziału, najwyższe zaś przekraczać równowartość 6 łokci samodziału (GII 255 221 ). Jeśli wysokość należnej dziesięciny nie przekraczała 5 łokci samodziału miała ona być w całości przekazana na pomoc osobom potrzebującym (purfamenn, GII 256 224 ), chyba że biskup dla danej diecezji podjął jednorazową decyzję, że ma ona zostać przekazana na utrzymanie wskazanych przez niego kościołów (GII 259 230 ). Dziesięcinę w wysokości 6 łokci samodziału, zwaną skipitíund (dosłownie „podzielna dziesięcina”) - dzielono na cztery równe części, z których pierwszą przeznaczano na pomoc potrzebującym (purfamannatíund, GII 256 224 ), drugą przekazywano biskupowi dla danej diecezji (biskupstíund, GII 257 225 ), trzecią i czwartą zaś kolatorowi kościoła o statusie wyższym niż kaplica, kirkjutíund miała zostać przeznaczona na utrzymanie zabudowań kościelnych, preststíund na wynagrodzenie dla księdza (GII 258 $226-227$ ). Poborem i podziałem pierwszej części dziesięciny zajmowali się przedstawiciele lokalnej wspólnoty sąsiedzkiej (tzw. sóknarmenn), drugą pobierały osoby wskazane przez biskupa, trzecią i czwartą osoby sprawujące pieczę nad danym kościołem.

Purfamannatíund należało przekazać najpóźniej w Dzień Wspomnienia Świętego Marcina (tj. 11 listopada) lokalnym sóknarmenn, którzy następnie rozdzielali zebrane środki pomiędzy potrzebujących z danej wspólnoty sąsiedzkiej (GII 256 224 ). Biskupstíund miała $\mathrm{z}$ kolei być przekazana gospodarzowi wyznaczonemu do tego celu

\footnotetext{
${ }^{76} \mathrm{~W}$ średniowieczu na Islandii równolegle funkcjonowało kilka środków płatniczych, spośród których największe znaczenie miał samodział (vaðmál, wełniana tkania tkana na ręcznym krośnie stanowiąca główny islandzki towar eksportowy) oraz srebro. Wspólnym denominatorem była tzw. legalna uncja (lögeyrir). Jedna legalna uncja była równa sześciu łokciom samodziału. Na systemu pieniądza towarowego funkcjonującego w średniowieczu na Islandii zob. S.H. GuLLBEKK, Money and its Use in the Saga Society: Silver, Coins and Commodity Money, w: Viking Settlements and Viking Society Papers from the Proceedings of the Sixteenth Viking Congress, red. S. Sigmundsson, Reykjavík 2011, s. 176-188.
} 
przez właściwego biskupa spośród członków określonego hreppr (GII 257 225). Zgodnie z Sekcją Praw Chrześcijańskich Grágás biskup Hólar miał odwiedzić każdą wspólnotę sąsiedzką funkcjonującą na terenie jego diecezji co najmniej raz w roku, zaś biskup Skálholt nie rzadziej niż raz na trzy lata, celem „konsekracji kościołów, kaplic i oratoriów, udzielania sakramentu bierzmowania i wysłuchiwania spowiedzi" $\left(G I 5_{35-36}\right)$. W trakcie spotkań z wiernymi w jednym z kościołów leżących na terenie wspólnoty biskupi mieli też ogłosić, któremu z lokalnych gospodarzy członkowie hreppr mieli dostarczyć biskupstíund. Ostateczny termin płatności dziesięciny przeznaczonej dla biskupa przypadał na „czwartek, gdy minęły cztery tygodnie lata” (tj. między 7 a 13 maja). Jeśli jednak biskupi nie wywiązali się z ciążących na nich obowiązków, w tym zwłaszcza regularnego odwiedzania hreppar, wierni mieli prawo do wstrzymania wypłaty należnej im części dziesięciny (GII 257 225 w związku z GI $\ddagger 8199$ ). Dwie pozostałe części skipitíund, tj. środki przeznaczone na utrzymanie zabudowań kościelnych i wynagrodzenie księdza miał otrzymać właściciel gospodarstwa, na terenie którego został wzniesiony dany kościół (GII $\left.258_{226-227}\right)$.

\section{Spór o kontrolę nad majątkami kościelnymi i instytucjonalizacja islandzkiego Kościoła}

Z uwagi na ścisłą kontrolę jaką osoby świeckie sprawowały nad niemal wszystkimi wczesnymi islandzkimi kościołami, sposób poboru i przeznaczenie $3 / 4$ dziesięciny, oraz fakt, iż pierwsi lokalni kapłani rekrutowali się przede wszystkim z grona prominentnych wodzów aktywnie uczestniczących w życiu politycznym Islandii (kirkjugoðar), islandzki Kościół przez pierwsze półtora wieku od jego powołania charakteryzował się bardzo niewielkim stopniem instytucjonalnej niezależności ${ }^{77}$. Ścisłe przenikanie się stref świeckich i religijnych najlepiej ilustrują role w jakich islandzcy duchowni pojawiają się w źródłach narracyjnych dotyczących okresu Pjóðveldið. Jak wynika

\footnotetext{
${ }^{77}$ J.L. Byock, The Power and Wealth of the Icelandic Church: Some Talking Points, w: The Sixth International Saga Conference..., s. 89-101.
} 
z badań Orriego Vésteinssona, na 186 możliwych do zidentyfikowania w staroislandzkich źródłach księży żyjących w XII i XIII wieku, jedynie 23 wydaje się faktycznie wykonywać posługę kapłańską, pozostali są nam znani wyłącznie za sprawą działań w sferze profanum: 19 bierze czynny udział w starciach zbrojnych, kolejnych 8 przyłącza się do wypraw o charakterze militarnym, co najmniej 5 traci w nich życie, a wielu innych odnosi trwałe obrażenia (dla przykładu biskup Hólar Ketill Porsteinsson, będący jednocześnie prominentnym wodzem z rodu Möðruvellingar, stracił w potyczce oko). O 50 islandzkich duchownych żyjących przed upadkiem Wspólnoty wiemy, iż byli pryncypałami w sporach prawnych, a o dalszych 53, iż aktywnie wspierali strony zaangażowane we wróżdy. Księża wywodzący się z niższych warstw społecznych często występują w źródłach w charakterze posłańców, zwiadowców, a nawet szpiegów ${ }^{78}$.

Odrębna tożsamość instytucjonalna duchownych zaczęła się kształtować na Islandii dopiero w XII wieku za sprawą powołania pierwszych klasztorów - Pingeyrar założonego w 1133 roku, Munkapverá z 1155 oraz Pykkvibær utworzonego w 1168 roku (dwa pierwsze należały do zgromadzenia benedyktyńskiego, trzeci augustiańskiego ${ }^{79}$. Społeczność zakonna na Islandii była niewielka - dostępne nam źródła zawierają informację raptem o 95 osobach, które przed 1300 rokiem prowadziły na wyspie życie konsekrowane ${ }^{80}$ - jednakże jej członkowie byli pierwszymi lokalnymi duchownymi, którzy postrzegali się jako osobną klasę społeczną. Z tego też kręgu wywodził się pierwszy reformator islandzkiego Kościoła biskup Skálholt św. Porlákr Pórhallsson, między 1168 a c. 1175 rokiem przeor a następnie opat klasztoru w Pykkvibær ${ }^{81}$.

\footnotetext{
${ }^{78}$ O. VÉsteinsson, The Christianization..., s. 211-212.

${ }^{79}$ J. JóH Annesson, Íslendinga..., s. 192-200. Łącznie na Islandii w średniowieczu funkcjonowało 11 klasztorów, w tym dwa żeńskie.

${ }^{80}$ J. Jesch, Early Christians in Icelandic History. A Case Study, Nottingham Medieval Studies 31 (1987), s. 17-36.

${ }^{81} \mathrm{Na}$ temat życia i posługi św. Porláka zob. K. Wolf, Pride and Politics in Late-Twelfth-Century Iceland: The Sanctity of Bishop Porlákr Pórhallsson, w: In Sanctity
} 
Posługa biskupia św. Porláka (1178-1193) przypadła na okres sprawowania urzędu arcybiskupiego w Niðaróss przez Eysteinna Erlendssona (1161-1188) i Eirika Ivarssona (1189-1205), dwóch norweskich arcybiskupów, aktywnie zaangażowanych w propagowanie na terenie podległej im archidiecezji gregoriańskiej doktryny libertas ecclesiae. W szeregu listów skierowanych do islandzkich biskupów Eysteinn i Eirik nakazywali im propagowanie wstrzemięźliwości seksualnej wśród osób duchownych, wprowadzenie zakazu noszenia przez przedstawicieli kleru broni i angażowania się w postępowania przed świeckimi sądami, a w wreszcie także zakazujący im udzielania święceń wodzom (goðar ${ }^{82}$. W świetle dostępnych nam staroislandzkich źródeł biskup Porlákr ze szczególną gorliwością wdrażał wśród ogółu islandzkich wiernych normy obyczajowe ${ }^{83}$. Mógł on też jednak podjąć się próby uzyskania ograniczonej kontroli eklezjalnej nad prywatnymi majątkami kościelnymi w duchu doktryny ius patronatus, co wedle kronikarzy miało doprowadzić do jego konfliktu z najpotężniejszymi lokalnymi wodzami (zob. zwł. Oddaverja páttr stanowiącą część Porláks saga byskups w wersji B i C) $)^{84}$. Odnotowany w źródłach przebieg tego sporu, znanego obecnie jako staðamál, jest uznawany przez współczesnych historyków za wyolbrzymiony ${ }^{85}$, niemniej jednak faktem jest, iż po śmierci św. Porláka w 1193 roku, wskutek zabiegów skonfliktowanych z nich goðar, tron biskupi w katedrze Skálholt objął Páll Jónsson (nieślubny syn potężnego wodza Jóna Loftssona i siostry Porláka Ragnheiðr Pórhallsdóttir), który istotnie spowolnił wprowadzanie gregoriańskich reform na Islandii (zob. Páls saga biskups).

in the North. Saints, Lives, and Cults in Medieval Scandinavia, red. T.A. DuBois, Toronto 2008, s. 241-70.

${ }^{82}$ Diplomatarium Islandicum..., tom 1, s. 290-291.

${ }^{83}$ Tamże, s. 240-241.

${ }^{84}$ Żywot Biskupa Porláka zachował się do czasów współczesnych w trzech różnych wersjach. Na temat istniejących między nimi różnic zob. wstęp do The Saga of Bishop Thorlak. Porláks Saga Byskups, London 2013, s. vii-xxi.

${ }^{85}$ O. VÉsteinsson, The Christianization..., s. 115-123. 
Konflikt pomiędzy islandzkimi wodzami a Kościołem został odnowiony w zintensyfikowanej postaci w pierwszej dekadzie XIII wieku, gdy diecezję Hólar objął biskup Guðmundr Arason, zestawiany niekiedy w islandzkiej historiografii ze św. Tomaszem Becketem ${ }^{86}$. Obrany w nadziei na to, że będzie posłusznym wykonawcą woli swych arystokratycznych patronów Guðmundr szybko obrócił się przeciwko nim, co doprowadziło do serii starć zbrojnych, jego wygnania z diecezji, tułaczki po kraju i wymuszonych wieloletnich pobytów w Norwegii. Powodem sporu była w tym przypadku jego chęć sprawowania wyłącznego zarządu nad majątkiem katedralnym oraz wyłączenia duchownych spod jurysdykcji świeckich sądów. Konflikt ten zakończył się dopiero, gdy za sprawą podeszłego wieku i problemów ze wzrokiem biskup Guðmundr przestał być postrzegany przez wodzów jako niebezpieczny przeciwnik (zob. Guðmundar saga biskups).

Po śmierci Guðmunda Arasona w 1237 roku aż do upadku pjóðveldið i poddania Islandii norweskiej koronie w 1264 roku, kolejni norwescy arcybiskupi powierzali kierowanie obiema islandzkimi diecezjami własnym rodakom, których głównymi celami wydaje się być wzmacnianie instytucjonalnej odrębności lokalnego kościoła oraz wspieranie stronników norweskiego króla w wewnętrznym konflikcie, w którym pogrążone były wówczas islandzkie elity. Pierwszy z owych celów realizowali oni przede wszystkim na drodze wysiłków w promowaniu celibatu duchownych. Najpierw od około 1240 roku wśród prezbiterów, a po 1260 roku także w odniesieniu do diakonów i subdiakonów. Starania te zostały zwieńczone już po utracie przez Islandię niepodległości wprowadzeniem w 1275 roku ramach tzw. Nowych Praw Chrześcijańskich obowiązkowego celibatu dla wszystkich osób wyświęconych ${ }^{87}$.

Po upadku Pjóðveldið został również rozstrzygnięty konflikt o kontrolę nad prywatnymi kościołami. Druga runda staðamál rozpoczęła się w 1269 roku, kiedy na wyspę dotarł nowy biskup Skálholt Árni Porláksson, któremu arcybiskup Niðaróss nakazał objęcie we

\footnotetext{
${ }^{86}$ G. KARLsson, Iceland's..., s. 42.

${ }^{87}$ O. VÉsteinsson, The Christianization..., s. 234-237.
} 
władanie wszelkich staðir (Árna saga biskups, rozdz.13-14). Działania zmierzające do realizacji tego polecenia spotkały się jednak z silnym oporem przedstawicieli lokalnej arystokracji, przez co w rozstrzygnięcie sporu musieli włączyć się król Magnús VI i arcybiskup Jón Raude, którzy w 1273 roku opowiedzieli się po stronie biskupa Árniego. Za sprawą jednak wewnętrznego konfliktu do jakiego doszło w Norwegii po śmierci Magnúsa, skutkiem którego było okresowe uchylenie wszystkich norm eklezjalnych wydanych za czasów panowania tego ostatniego ${ }^{88}$, ostateczne rozstrzygnięcie kwestii kontroli nad islandzkimi staðir zapadło dopiero w 1297 roku. Na mocy porozumienia z Ögvaldsnes islandzcy biskupi przejęli kontrolę nad wszystkimi kościołami, na rzecz których dokonano donacji więcej niż połowy gospodarstwa, przy którym zostały wzniesione ${ }^{89}$. Wydarzenie to jest uznawane za symboliczny koniec dominacji islandzkiej arystokracji nad lokalnym Kościołem i zmierzch okresu goðakirkja ${ }^{90}$.

\section{Goðakirkja - the Icelandic Church During the Commonwealth Era}

Goðakirkja (the chieftains church) is the name given by the modern Icelandic historians to the early Catholic Church of Iceland. The name signifies the unusually large amount of control which the prominent members of the laity used to have over the Icelandic church and its properties. All the churches in Iceland except the one built next to the General Assembly (Alpingi) were privately owned and managed. Most of the tithe was collected by laymen. The secular elites took part in electing the local bishops, and all the commands of the foreign archbishops were treated as "new laws" (nýmeli), temporary resolutions which were to be in force only for three years, after which they were to be considered anew by the members of the Law Council (Lögrétta). The aim of present article is to retrace the early development of the institutional Church in medieval

\footnotetext{
${ }^{88}$ S. BAGge, From Viking..., s. 303-312.

${ }^{89}$ Diplomatarium Islandicum. Íslenzkt fornbréfasafn, tom 2 Reykjavík 1893, s. 324-325.

${ }^{90}$ G. KARLsson, Iceland's..., s. 99.
} 
Iceland. Special consideration is given to the conversion of Icelanders, the functions of the early church buildings, the differences between various classes of priest, and the unusual nature of the tithe collected in Iceland. Finally, I outline the so called staðamál that is the conflict over the control of the privately built churches.

SŁowA KLUCzowE: chrystianizacja Islandii; islandzki Kościół; kościół wodzów; Islandzka Wolna Wspólnota

Keywords: The Christianization of Iceland; Icelandic Church; the chieftains church; the Icelandic Commonwealth

\section{Nota o AUTORzE}

Dr WŁoDZIMIERz GogŁozA - doktor nauk prawnych, adiunkt WPiA UMCS, post-doc na Wydziale Prawa Uniwersytetu Islandzkiego w Rejkiawiku, stypendysta Fundacji Rozwoju Systemu Edukacji, Culture and Animals Foundation oraz Animals and Society Institute. 